\title{
The Using of E-Office in Efforts to Achieve Company Performance with Excellent Performance Model
}

\author{
Hani Damayanti Aprilia ${ }^{1,{ }^{*}}$ Damayanti ${ }^{2}$, \\ ${ }^{1}$ Business Administration Department, University of Lampung \\ ${ }^{2}$ Office Administration Department, University of Lampung \\ ${ }^{*}$ Corresponding author. Email: hani.damayanti@fisip.unila.ac.id
}

\begin{abstract}
The development of the times and technology demands the creation of a system that can improve company performance. One system that is believed to be able to improve company performance is the use of e-office. With e-office, companies can achieve optimal performance. Achieving optimal company performance with the Excellent Performance Model (MKE) is the focus of various companies today. This study aims to identify, describe, and analyze the use of e-office in improving company performance. The method used in this research is descriptive research type, using a qualitative approach - data collection techniques with interviews and literature study. Technical data analysis uses interactive model data analysis with triangulation for data validity. The results show that e-office is able to provide convenience for companies in the administration of work to create a paperless office. The company's support for the enormous e-office, combined with the company's human capital, is an added value for the company. for achieving excellent performance.
\end{abstract}

Keywords: e-office, company performance, excellent performance model

\section{INTRODUCTION}

Achievement of performance with the Excellent Performance Model (MKE) is the focus of various companies today, because MKE can help each company to improve its performance, both individual performance, process performance and result performance. MKE is a guide for companies to achieve excellent performance. MKE is applying an effective management tool by integrating managerial processes and achieving business results [1].

Achievement of performance with MKE focuses on human capital. Matthewman \& Matignon define human capital as the accumulation of knowledge, skills, experience and other relevant workforce attributes within an organization's workforce and drive productivity, performance and achievement of strategic goals. Companies that prioritize human capital as an investment and not as a cost are likely to achieve excellent performance [1]. Nowadays more and more companies are interested in using invisible assets and human capital as a way to gain an advantage over competitors (Noe) [1].
One of the companies that focuses on achieving excellent performance is Life Insurance Company X. Life Insurance Company $\mathrm{X}$ shows strong business performance outpacing the growth of the life insurance industry in Indonesia. Based on the ranking conducted by Investor magazine every year, since 2009 Life Insurance Company X has had the best performance among other life insurance companies [2].

The low level of financial literacy has become a major challenge for companies, which is reflected in the low penetration of life insurance, where only about $4 \%$ of the total population in Indonesia are individual life insurance policyholders. So to answer this challenge, the company focuses on developing the quality and quantity of life insurance marketers in Indonesia [2].

The success of the excellent performance of Life Insurance Company $\mathrm{X}$ is supported by the high performance of individual marketers owned by the company in acquiring customers, which is reflected in the size of the overall net premium collected by the 
company. Life Insurance Company $\mathrm{X}$ is one of the insurance companies that boosts premium income with the power of agency distribution (marketers). The distribution agency becomes the power of the distribution engine that works amazingly [3].

The development of marketers' ability, professionalism, and quality is very necessary, because when compared to other business sectors, insurance companies are unique when viewed from the products offered. Where the products offered are not real products that can be enjoyed today, but rather to prepare for the future, be it protection (protection) or investment. It will be easier to offer products that can be enjoyed today and are tangible, compared to offering products that are just like a dream and are felt to be less needed because the awareness of insurance among the Indonesian people is still very low. So that the main thing in responding to this challenge is the development of the ability, professionalism, quality and quantity of marketers.

From the results of company document searches in 2021, the development of marketers' ability, professionalism, and quality is a high priority and a key strategy for the company's growth. The development of marketers is not fully managed by the company, but by the Independent Marketing Office (KPM) or agency. A manager leads each Independent Marketing Office (KPM) or agency. This manager has the task to be able to develop the ability, professionalism and quality of marketers based on the goals to be achieved by the company.

KPM or agency are given the flexibility to expand the scope of marketers outside the area of their respective operational offices. So that in one area there may be several different agencies. Although the company's support and the outline of a marketing force development program have been established and become the guideline for all managers in developing competent marketers, not all agencies have the same level of success. Agency that is successful in developing marketers' ability, professionalism, and quality will produce many SUM (Senior Unit Manager) and UM (Unit Manager).

The development of the times and technology forces every individual to be smart at work. One of them is by utilizing technology in completing the work. The marketers at Life Insurance Company X are no exception. Customers spread across various regions will be difficult to reach if the marketers still work manually. Marketers are required to work by utilizing technology to create good relationships with companies and customers through a system called electronic office. Electronic Office (e-office) is a system related to administration that virtually centralizes the components of an organization, where data, information and communication are created through telecommunications media (Arief) [4]
The use of technology in the work activities of marketers, of course, demands new responsibilities. Marketers are also required to continue improving their knowledge and skills, in accessing information and disseminating information through applications provided by the company [5]. Advances in technology have brought great changes to an organization or company. So that every company is required to be able to have various applications whose purpose is to make it easier for employees to complete their work [6]

\section{METHOD}

The method used in this study is a descriptive type of research with a qualitative approach to produce a description in the form of written or spoken words of the people and observed behavior [7]. The object of research is a life insurance company with a research focus, namely the using of e-office to achieve company performance with an excellent performance model. Collecting data by interview and literature study, analyzed by interactive model and tested the validity of the data using triangulation technique [8].

\section{RESULT AND ANALYSIS}

\subsection{E-Office to Achieve Corporate Performance}

The development of the times and technology forces every individual to be competent at work. One of them is by utilizing technology in completing work. The marketers at Life Insurance Company $\mathrm{X}$ are no exception. Customers spread across various regions will be difficult to reach if the marketers still work manually. Interviews with SUM stated that marketers are required to work by utilizing technology to create good relationships with companies and customers through a system called electronic office (E-Office) [4].

E-office implemented in a company will certainly help employees in completing their office tasks. The use of e-office will also facilitate company leaders. Because with the e-office, evaluation and completion of reports can be done quickly based on data that has been recorded and is in the e-office system. So, there is no need to bother collecting physical reports and creating a paperless office. The report can be downloaded in its entirety to see if the job is done well or not. This report can then be used to assess employee performance [9].

The availability and use of modern office equipment will greatly affect employees' activities and performance in an organization or company. The availability of various applications provided by the company to support the work of its employees will 
have a positive impact in the form of good performance and increased work productivity. In addition, the availability of various applications will certainly ease the work of marketers. Time will also be shorter in completing various tasks. The availability of various applications that support work must be balanced by the knowledge and skills of employees to be able to use the various applications available. Therefore, the effectiveness of the functions of the application depends on the knowledge, skills, and expertise, possessed by each employee [9].

From the results of interviews and company document searches in 2021, the support provided by the company for the use of E-office in the company includes:

1) PRUaccess, is a web-based application specifically made to meet the needs of Policy Holder customers. PRUaccess can provide policy data information whenever customers need it. PRUaccess can be accessed 24 hours per day and seven days a week, or in other words, can be accessed every day. Through PRUaccess, policyholder customers can monitor the status and benefits of the policy more closely. Although PRUaccess is an application that is intended for customers and not for marketers, marketers must master and be able to operate the PRUaccess application and provide tutorials on how to use the PRUaccess application to customers. PRUaccess can be accessed either through computers, laptops, or mobile phones via PRUaccess mobile.

With PRUaccess, marketers have many advantages. Marketers can save time, effort, and money to visit or fulfill policyholder customer calls when they need information regarding their insurance policies. In addition to monitoring policy developments, policyholder customers can also printelectronic policies through the PRUaccess application. In addition, with PRUaccess, savings can be made in printing physical documents as reports to customers. With PRUaccess, policyholder customers can immediately see the progress and reports of their insurance funds. In addition, policyholder customers can also access letters sent by the company through the My Letter and Statement facility.

Letters available on the My Letter and Statement facility include:

1. Transaction Statement.

2. Failed Debit/Dishonor Credit Card, if there is a debit failure for customers who use the Autodebit premium payment method.
Customers who have used Pruaccess can have an electronic policy. is an agreement in electronic form, which includes Policy Summary, Life Insurance Request Letter (SPAJ) that has been approved by the company, tables, calculation formulas, general policy provisions, special provisions and other provisions (if any) along with any additional or its amendments that contain the terms and conditions of the life insurance agreement between the company and the policyholder.

The Electronic Policy is available for PRUlink assurance account and PRUlink sharia assurance account owners and can be accessed through PRUaccess. If we have difficulty accessing the Electronic Policy, we can contact the Marketing Personnel or the Customer Line.

Apart from the internet, PRUaccess can also be accessed via PRUaccess Mobile. PRUaccess Mobile is a mini version or mobile version of PRUaccess that can be accessed via mobile phones. PRUaccess Mobile contains features that are frequently accessed from PRUaccess, such as policy information, proposal information, and the value of the policy.

The menus available in PRUaccess Mobile include:

1. Proposal Information, including:
a) Proposal Status
b) Amount of Premium
c) Basic and Additional Insurance
Information
d) Types of Funds and Investments
e) Primary and Additional Insured Information

2. Policy Information, including:
a) Unit Balance, Unit Value and Type of Investment Fund
b) Amount and Maturity of Premium
c) Policy Status, Active or Inactive
d) Top-up Transactions and Withdrawals
e) Claim Submission Status

3. e-Transactions, including:
a) Top-up
b) Switching \& Redirection
c) Continue Premium Payment
d) My Supporting Document
e) Transaction History

2) Sales Force Automation (SFA), is a web-based application that is useful for facilitating communication and information from every 
marketer. SFA is a weapon for marketers in marketing their insurance products. By using SFA, marketers can download proposals for prospective customers, access customer data, and even marketers can check the amount of commission they earn. Thus, marketers become more productive because marketers can see their performance through earning commissions. With SFA, marketers can save time, money and effort. SFA makes the work of marketers easier, because marketers do not need to carry many physical documents related to customers or customer policies. SFA is accessible both on desktop and on mobile.

3) PRUsales Academy is a facility provided by the company that is useful for marketers as a place to learn and practice. On March 18, 2013, the company opened PRUsales Academy in Kasablanka, Jakarta, a training and development center for marketers from agency and partnership distribution channels. Supported by certified trainers, PRUsales Academy has an integrated management system using the latest technology and information systems. PRUsales Academy is expected to increase the number of qualified marketers, because PRUsales Academy provides e-learning and e-exam facilities that enable marketers to obtain certificates from the Indonesian Life Insurance Association (AAJI) quickly and in large numbers.

Thus, it can be concluded that the e-office used is very complete. Apart from being intended for marketers to complete their work, e-office can also be used by marketers to establish communication with customers. Utilization of e-office for marketers is not only to achieve job targets, but can also be used to assess their performance.

By using an application provided by the company, working hours are shortened. The market reach of marketers has also become wider. The world is getting smaller because marketers don't have to meet face-to-face with potential customers or their customers. Everything can be done virtually [10].

Even though the company has implemented eoffice, it does not mean that all company activities have become more effective and efficient. There are several obstacles faced by the company in the use of e-office in the company. This constraint comes from the behavior of employees. This condition is related to work culture and individual motivation. Work culture and individual motivation are components of human capital [11]. That is, even though the company provides work facilities, if the employee's motivation is problematic, of course it will also have problems with its performance. If individual performance is not achieved, then the company's performance will also be difficult to achieve.

\section{a. Work Culture}

The company's work culture is greatly influenced by the organizational atmosphere within the company. The figure of a leader who can foster his fostered marketers strongly supports the creation of a comfortable organizational atmosphere, to create a harmonious relationship between marketers, leaders and marketers. With a conducive organizational atmosphere, marketers can work optimally. The results of the interview with AUM explained that marketers will remain enthusiastic even though they face problems in the field if the leader pays attention and is responsive to the problems faced by marketers. In addition, activities outside of work activities will also provide a comfortable atmosphere at work.

Interviews with UM and marketers explained that an arisan is held every month where marketers can bring all family members to the arisan event. Not only social gathering activities that make marketers comfortable, but also during the event an assessment is made for the best marketers by the leader. The best marketers will get a reward from the leader. The reward can be in the form of cash or Smartphone. This reward does not come from the company but is an initiative of the leader to spur the enthusiasm of marketers to get as many customers as possible. This reward is not only a motivation, or comfort for marketers in doing their jobs but also makes marketers feel very appreciated. This award has a huge influence on marketers' performance. Being given a reward outside of the commissions and bonuses that the company has given will make marketers work harder and more responsible for their work.

\section{b. Individual Motivation}

From the results of interviews with Senior Unit Managers, Unit Managers, Associate Unit Managers, and Marketers, the motivations for individuals within marketers include commissions, bonuses, training at home and abroad, trips to foreign countries, and support leaders. Marketers will not achieve higher performance than before if there is no motivation to do their work. One of the motivations to become a marketer for insurance products is compensation in commissions, bonuses, international training, and travel abroad. The statement indicates this by SUM in interviews, ME, and marketers. Company awards for the achievements of marketers such as commissions, bonuses, training at home and abroad, trips to foreign countries can motivate 
marketers to improve and improve their performance to become professional marketers.

From the interviews, it is also known that the motivation that underlies the marketers is external motivation, namely motivation that is built on internal motivation and is within the company so that it is very dependent on the assumptions and techniques used by managers in motivating their subordinates [12]. These motivations include commissions \& bonuses, awards and career paths [13].

In addition to commissions, bonuses, international trainings, and overseas travel, another thing that motivates marketers is the support from the leader. This is based on the results of interviews with UM and AUM that a leader who supports his fostered marketing staff will greatly motivate his marketing staff to obtain closing customers. Leaders who are attentive and responsive to the problems faced by marketers in the field will also gain more experience and knowledge.

In a company, motivation becomes a very complex issue. This is influenced by the needs and desires of each different person. These differences include differences in biological, psychological, and learning experiences that differ from person to person. Leaders in a company must be able to understand this condition, because motivation is one of the factors for the smooth running of a company in achieving its goals.

Motivation in a person, there are those that come from within himself, but there are also those that come from outside himself. Motivation that comes from within a person is called internal motivation. Meanwhile, what comes from outside is called external motivation. Both, both internal motivation and external motivation must be appropriately managed by company leaders to motivate their subordinates.

Leaders can take advantage of external motivation in both positive and negative terms. Practice positive motivation by rewarding employees for good work. Negative motivation practice by giving punishment if the implementation and work result is bad. Both of these motivations can be used by company leaders to encourage employees. This is very important to do, because previous research has proven that positive motivation, both internal and external, really helps companies improve employee performance [14][15][16][17]. The positive influence of motivation on performance, illustrates that motivation becomes a supporting factor if the organization or company wants to improve the performance of its employees [18]. Without support from leaders, individual motivation will be difficult to support employee performance improvement [19].

\subsection{Company Performance Achievement using the Excellent Performance Model}

Company activities that show company performance related to the Excellent Performance Model, namely [1][20]:

a) Leadership that is actualized by the presence of leaders at the UM, SUM and AM levels in agency offices.

b) Strategic planning carried out by the head office.

c) Focus on customers and the market which is actualized on services for customers and a wide range of products that are tailored to customer needs and keep up with the times.

d) Process management. SUM explained in the interview that the process becomes very important even though the results are equally important. Maximum results require a series of processes that are not easy, especially in a customer closing process for life insurance products. Marketers must have a strong mentality, never give up and have more patience in order to successfully close, because not all Indonesians realize the importance of life insurance. This low awareness of the community causes marketers to be often rejected, ignored, and received unfavorably, at this time the process works.

e) Business results. The results of this business include the results obtained which are recorded in the company's premium income and a large number of awards received.

MKE is built on corresponding values and performance. The Excellent Performance Model emphasizes practices to create a workplace that can produce excellent performance and develop employees so that they and the company can adapt to the changing business environment. So that individual performance will be obtained which will ultimately create company performance. These values include [1][20]:

1. Visionary leadership;

2. Customer-driven excellece;

3. Organizational and personal learning;

4. Valuing employees and partnership;

5. Agility;

6. Focus on the future;

7. Managing for innovation;

8. Management by fact;

9. Social responsibility;

10. Focus on results and creating value;

11. System perspective; 


\section{CONCLUSION}

From the above explanation, it can be concluded that e-office is able to provide convenience for marketers and companies both in work administration, customer relations, and creating a paperless office. The company's support for the enormous e-office, combined with the company's human capital, is an added value for the company. Therefore, the use of e-office for achieving excellent performance is the right choice for the company.

\section{AUTHORS' CONTRIBUTIONS}

Hani Damayanti Aprilia: Conceptualization, Writing original drafts, Reviewing and Editing manuscripts, Collecting secondary data, Interviews, Data analysis, Visualization of research results. Damayanti: Interview, Data analysis, Review.

\section{ACKNOWLEDGMENTS}

Thank you to the Faculty of Social and Political Sciences, Lampung University, for funding this research through the 2021 DIPA FISIP UNILA.

\section{REFERENCES}

[1] J. L. Gaol, A to Z Human Capital Manajemen Sumber Daya Manusia: Konsep, Teori, dan Pengembangan dalam Konteks Organisasi Publik dan Bisnis. Jakarta: Grasindo, 2014.

[2] Investor, "Cetak Biru Perbankan Versi OJK," Edisi Khusus. Vol. XVI, No. 253., Jakarta, 2014.

[3] H. D. Aprilia, N. Efendi, and A. Rifa'i, "Human Capital Di Era Digital," J. Perspekt. Bisnis, vol. 3, no. 1, pp. 21-32, 2020, doi: 10.23960/jpb.v3i1.10.

[4] N. N. Izzati and Marsofiyati, "Penerapan EOffice Dalam Upaya Peningkatan Kinerja Bisnis Perusahaan," Ekon. Bisnis, vol. 18, no. 2, pp. 160-164, 2020, doi: 10.32722/eb.v18i2.1436.

[5] P. A. Oteng and P. A. Seidu, "ADRRI JOURNAL OF ARTS AND SOCIAL SCIENCES ISSN : 2343-6891 ISSN-L : 2343-6891 ADRRI JOURNAL OF ARTS AND SOCIAL SCIENCES The Impact of Modern Offic e Technology on the Secretary 's Performance in Some Selected Business Organizations in the Takoradi Metrop," vol. 13, no. 12, pp. 1-10, 2016.

[6] M. Akpomi and P. Ordu, "Modern office technology and the secretarys productivity in private business organisations," African J. Bus. Manag., vol. 3, no. 8, pp. 333-339, 2009.

[7] J. L. Moleong, Metodologi Penelitian Kualitatif. Bandung: PT Remaja Rosdakarya, 2013.
[8] A. M. Miles, M.B. dan Huberman, Analisis Data Kualitatif (Buku Sumber tentang Metode-Metode Baru). Jakarta: Universitas Indonesia, 2009.

[9] M. I. Aliata and S. A. Hawa, "Modern Office Technology and the Performance of the Professional Secretary in Contemporary Organisations in Ghana," vol. 3, no. 4, pp. 52-57, 2014.

[10] A. Charles, "the Relevance of Office Technology and Management (Otm ) Skills in Organizational Growth and Development .," Int. J. Adv. Acad. Res., vol. 1, no. 1, pp. 113,2006

[11] A. Mayo, "The Role of Employee Development in The Growth of Intellectual Capital.," Pers. Rev., vol. 29, no. No. 4, April, pp. 521-533, 2000.

[12] S. Reksohadiprodjo and T. H. Handoko, Organisasi Perusahaan. Yogyakarta: BPFE, 2001.

[13] K. T. Rahmawati, "Pengaruh Kompensasi terhadap Kinerja Karyawan pada Asuransi Jiwa Bersama Bumi Putera 1912 Cabang Pasuruan," UIN Maulana Malik Ibrahim, 2009.

[14] T. Jayaweera, "Impact of Work Environmental Factors on Job Performance, Mediating Role of Work Motivation : A Study of Hotel Sector in," Int. J. Bus. Manag., vol. 10(3), pp. 271-278, 2015, doi: 10.5539/ijbm.v10n3p271.

[15] M. Ghaffari, S., Burgoyne, J. and Nazri, "The Influence of Motivation on Job Performance : A Case Study at Universiti The Influence of Motivation on Job Performance : A Case Study at Universiti Teknologi Malaysia," Aust. J. Basic Appl. Sci., vol. 11(4), pp. 9299, 2017.

[16] J. R. S. Ghaffari, Sara., Shah, Ishak Mad., John Burgoyne., "The Influence of Motivation on Job Performance : A Case Study at Universiti Teknologi Malaysia The Influence of Motivation on J ob Performance : Universiti Teknologi Malaysia A Case Study at," Aust. J. Basic Appl. Sci., vol. 11(4), pp. 92-99, 2020, [Online].

Available: http://creativecommons.org/licenses/by/4.0/ .

[17] S. Elvina and L. Z. Chao, "A Study on The Relationship Between Employee Motivation and Work Performance," IOSR J. Bus.

Manag., vol. 21, no. 3, pp. 59-68, 2019, doi: $10.9790 / 487 X-2103025968$.

[18] Y. Kuswati, "The Effect of Motivation on Employee Performance," Budapest Int. Res. Critics Inst. Humanit. Soc. Sci., vol. 3, no. 2, pp. 995-1002, 2020, doi: 10.33258/birci.v3i2.928.

[19] N. F. Sadly, "Analysis of Empowerment of 
Human Resources (Member) in Improving Career Development (Case Study at PT.

HNI-HPAI Bussines Center (BC9)

Subdistrict Sudirejo 1)," Budapest Int. Res.

Critics Inst. Humanit. Soc. Sci., vol. 4, no. 2, pp. 2557-2567, 2021, doi:

10.33258/birci.v4i2.1960.

[20] M. Voss, "Criteria for Performance

Excellence Framework," 2012.

https://www.youtube.com/watch? $=\mathrm{CVqccfN}$

sLA8. 